\title{
Cell-free circulating tumor DNA in cancer
}

\author{
Zhen Qin ${ }^{1,2}$, Vladimir A. Ljubimov ${ }^{3}$, Cuiqi Zhou' ${ }^{1}$ Yunguang Tong ${ }^{1,4^{*}}$ and Jimin Liang ${ }^{2^{*}}$
}

\begin{abstract}
Cancer is a common cause of death worldwide. Despite significant advances in cancer treatments, the morbidity and mortality are still enormous. Tumor heterogeneity, especially intratumoral heterogeneity, is a significant reason underlying difficulties in tumor treatment and failure of a number of current therapeutic modalities, even of molecularly targeted therapies. The development of a virtually noninvasive "liquid biopsy" from the blood has been attempted to characterize tumor heterogeneity. This review focuses on cell-free circulating tumor DNA (ctDNA) in the bloodstream as a versatile biomarker. ctDNA analysis is an evolving field with many new methods being developed and optimized to be able to successfully extract and analyze ctDNA, which has vast clinical applications. ctDNA has the potential to accurately genotype the tumor and identify personalized genetic and epigenetic alterations of the entire tumor. In addition, ctDNA has the potential to accurately monitor tumor burden and treatment response, while also being able to monitor minimal residual disease, reducing the need for harmful adjuvant chemotherapy and allowing more rapid detection of relapse. There are still many challenges that need to be overcome prior to this biomarker getting wide adoption in the clinical world, including optimization, standardization, and large multicenter trials.
\end{abstract}

Keywords: Circulating tumor DNA, Liquid biopsy, Cancer

\section{Background}

Cancers figure among the leading causes of morbidity and mortality worldwide, with approximately 14 million new cases and 8.2 million cancer-related deaths in 2012 [1]. The number of new cases is expected to rise by approximately $70 \%$, from 14 million in 2012 to 22 million within the next two decades [1]. Surgery, adjuvant systemic treatment, and targeted therapies have markedly improved cancer outcomes over the past 10 years. However, many patients still die due to tumor metastasis and drug resistance [2]. Tumor heterogeneity and clonal evolution introduce significant challenges in designing effective treatment strategies [3, 4]. Different tumor cells show distinct morphologic and phenotypic features, including cellular morphology, gene expression, metabolism, motility, proliferation, and metastatic potential [5]. Heterogeneity occurs both between tumors

\footnotetext{
*Correspondence: YunguangTong@ucla.edu;

jimleung@mail.xidian.edu.cn

${ }^{1}$ Department of Medicine, Cedars-Sinai Medical Center, David Geffen

School of Medicine at UCLA, Los Angeles, California 90048, USA

${ }^{2}$ School of Life Science and Technology, Xidian University, Xi'an 710126,

Shaanxi, P. R. China

Full list of author information is available at the end of the article
}

(intertumoral heterogeneity) and within tumors (intratumoral heterogeneity). Intratumoral heterogeneity, with spatially separated heterogeneous somatic mutations and chromosomal imbalances in primary tumors or metastases, provides a tremendous challenge for cancer treatment, since examining a tissue biopsy of a portion of tumor mass could miss therapeutically relevant lesions [6]. In addition, clonal evolution in the primary tumor is partly fueled by intratumoral heterogeneity. When metastases develop, clonal evolution continues to occur under the selection pressure of anti-cancer treatments [6-8]. Molecularly targeted cancer therapies require serial monitoring of the tumor genomic makeup. However, obtaining consecutive tissue biopsies is costly, sometimes inaccessible, and associated with potential morbidity. Therefore, inability to capture spatial and temporal heterogeneity during tumor evolution results in the failure of cancer systemic treatments, requiring the development of novel approaches to detect tumor heterogeneity.

Recent progress in the analysis of blood samples for circulating tumor cells (CTC) or cell-free circulating tumor DNA (ctDNA) provides rapid, cost-effective, and noninvasive "liquid biopsy" surrogates, which give important 
complementary information on therapeutic targets and drug resistance mechanisms in cancer patients $[9,10]$. Apoptotic or necrotic tumor cells discharge DNA fragments into the circulating blood system. These DNA fragments are called cell-free ctDNA. Cell-free DNA was initially reported by Mandel and Metais [11] in 1948 in the blood of healthy individuals. Elevated levels of ctDNA have been found in blood plasma and serum of cancer patients compared to healthy controls [12-21]. This review focuses on ctDNA and discusses the biological and technical aspects, clinical applications in cancer diagnostics, and perspectives and challenges.

\section{Circulating tumor cells (CTC)}

CTCs are tumor cells shed into the bloodstream from primary and metastatic tumor deposits [22]. CTCs were initially detected in 1869 by an Australian physician Thomas Ashworth in a breast cancer patient's blood [23]. Analysis of CTCs in peripheral blood of cancer patients holds great promise for the early detection of invasive cancer and the management of advanced disease. CTC detection and retrieval require elaborate methods and cumbersome processes, including highly sensitive and specific analytic methods and complex enrichment steps $[24,25]$. Although techniques of CTC isolation are steadily improved with increasingly sophisticated technologies developed over the past years [26, 27], CTC identification and characterization still remain technically challenging. CTCs occur at very low concentrations of one tumor cell in the background of millions of blood cells. Particularly, patients with early-stage cancer present with extremely low CTC concentration, thus needing more sensitive assays and/or analysis of larger blood volumes, which is usually not feasible [25]. Furthermore, mechanism(s) causing CTCs to break off from the tumor are elusive; thus it is unclear whether CTCs represent the entire makeup of cancer cells in the tumor or only a subpopulation. CTCs and ctDNA likely have complementary roles as cancer biomarker since separate approaches possess distinct advantages. CTCs visualize intact cells for morphologic identification, associate with the metastatic process, and provide the unique opportunity for functional study and more comprehensive information including DNA, RNA, and protein-based molecular profiling [28]. Compared with CTCs, ctDNA is easier to isolate and more sensitive to detect. Therefore, as an alternative to CTC analysis, ctDNA appears to potentially provide superior source of genetic information, with the development of next-generation sequencing technologies.

\section{Origin and biological characteristics of ctDNA}

Cell-free DNA is released into circulation by various pathologic and normal physiologic mechanisms.
Fragments of DNA are shed into the bloodstream from dying cells during cellular turnover or apoptotic and necrotic cells $[29,30]$. Under normal physiologic circumstances, apoptotic and necrotic cells are cleared by infiltrating phagocytes and cell-free DNA levels are relatively low. However, this mechanism does not act effectively in the tumor mass. Most cell-free DNA fragments are measured between 180 and 200 base pairs (bp) [30-32], suggesting apoptosis as the predominant source of cellfree DNA in the circulation [30,33, 34]. In solid tumors, cell-free DNA can be also released through necrosis, autophagy, and other physiologic events induced by microenvironmental stress and treatment pressure [21, 35]. Unlike apoptosis, necrosis generates larger DNA fragments due to an incomplete and random digestion of genomic DNA [36]. Nevertheless, not all cell-free DNA originates from cell death. Live cells spontaneously release newly synthesized DNA as part of a homeostatically regulated system [29, 37-39]. Stimulation of lymphocytes also results in the release of large amounts of cell-free DNA in the absence of cell death [38, 40, 41]. In cancer patients, a fraction of cell-free DNA is tumorderived and is termed ctDNA. Cancer patients generally have much higher levels of ctDNA than healthy individuals, but the levels vary widely, from $0.01 \%$ to more than $90 \%[12-21,34]$. The variability of ctDNA levels in cancer patients likely associates with tumor burden, stage, vascularity, cellular turnover, and response to therapy $[34,42]$.

Stability of cell-free DNA is not well understood. Cellfree circulating DNA appears to be rapidly cleared and the spleen, liver, and kidneys are involved in the clearance mechanism [43, 44]. The half-life of cell-free fetal DNA was previously estimated to be $16 \mathrm{~min}$ [45]. By using paired-end massive parallel sequencing (MPS), the same group recently studied the kinetics of cell-free fetal DNA and found that the clearance of circulating fetal DNA occurred in two phases with different kinetics [44]. The initial rapid phase had a mean half-life of approximately $1 \mathrm{~h}$, whereas the subsequent slow phase had a mean half-life of approximately $13 \mathrm{~h}$ [44]. To date, very few studies addressed the clearance mechanism of ctDNA from plasma. Studies regarding the kinetics and clearance of circulating Epstein-Barr virus (EBV) DNA may indicate equivalent mechanisms [46-48]. Furthermore, it is also unknown whether other factors such as circadian rhythms, inflammation, or particular therapies affect ctDNA release and clearance.

Cancer harbors somatic genetic mutations and these tumor-specific alterations can be detected in ctDNA. Therefore, ctDNA carries genomic and epigenomic alterations concordant to the tumor mutational spectrum, such as point mutations, degree of integrity, rearranged 
genomic sequences, copy number variation (CNV), microsatellite instability (MSI), loss of heterozygosity $(\mathrm{LOH})$, and DNA methylation [49]. These biological characteristics discriminate ctDNA from normal cell-free DNA and assure ctDNA as a specific biomarker that provides personalized information to detect residual disease or monitor tumor progression during therapy.

\section{Technologies for ctDNA analysis}

Isolation of cell-free DNA for analyses of tumor-specific alterations is simple to implement from a clinical perspective. Circulating DNA is preferably extracted from plasma due to lower concentration of background wild-type DNA. The amount of cell-free DNA in serum can be 2-4 times higher than that in plasma [50], therefore, serum could be used for circulating DNA preparation. However, this is not recommended due to the possible contamination of lysed cellular DNA that would affect the relative levels of ctDNA. As described before, cell-free DNA has limited stability, thus cellfree DNA preparation should be completed promptly after blood draw.

The analysis of ctDNA is challenging and requires highly sensitive techniques due to the small fraction of tumor-specific DNA masked within background levels of wild-type cell-free DNA. Classical methods analyzing cell-free DNA include quantitative real-time polymerase chain reaction (PCR)-based, fluorescence-based, and spectrophotometric approaches [51-53]. More recently, a variety of digital genomic methods have been developed to improve identification of generic alterations in ctDNA. Digital PCR has now emerged as a sensitive tool to detect point mutations in ctDNA at low allele fractions [54], which comprises droplet-based systems [55, 56], microfluidic platforms for parallel PCR [10, 57, 58], and an approach called BEAMing (beads, emulsions, amplification and magnetics) (Table 1) [34, 59, 60].

Next-generation sequencing technologies are currently being applied to plasma DNA analysis. These high-throughput, low-cost, sequencing technologies identify widespread ctDNA alterations across wide genomic regions [61-63]. Targeted deep sequencing approaches have been used to analyze specified genomic regions in plasma DNA, including PCR-based targeted deep sequencing such as TamSeq [10, 57], SafeSeq $[64,65]$, and Ion-AmpliSeq ${ }^{\mathrm{TM}}[66,67]$ and capture-based targeted deep sequencing such as CAPP-Seq [68] (Table 1). Remarkably, whole genome sequencing provides novel opportunities for comprehensive characterization of the alteration profiles, not just limited to predefined or existing mutations in plasma DNA [69]. Genome-wide detection of chromosomal rearrangements and CNVs can be characterized in ctDNA, serving as tumor biomarkers with excellent sensitivity and specificity [70, 71]. Two genomewide methods, personalized analysis of rearranged ends (PARE) [70, 72] and digital karyotyping [73] can be applied to ctDNA detection (Table 1). PARE is a method for identifying specific somatic rearrangements in tumor tissue and subsequently developing PCRbased assays to detect these tumor biomarkers in the circulation [72, 74]. Digital karyotyping is a genomewide technique used to quantify the DNA copy number and novel sequences on a genomic scale. It has been applied to detect previously uncharacterized chromosomal changes and exogenous sequences in human tumors [73, 75, 76]. Moreover, recent implementation of whole-genome sequencing allows direct application to ctDNA analysis, and has provided an unprecedented view of somatic chromosomal alterations and CNVs on a genome-wide scale [74, 77, 78]. Undoubtedly, with continuous improvements in the sensitivity of genomic approaches, next generation sequencing techniques will play a pivotal role in ctDNA analysis for future clinical applications.

Evaluation of cell-free DNA integrity index is a different approach to identify ctDNA alterations and constitutes an independent indicator different from any specific genomic changes. DNA integrity index is measured as the ratio of long to short DNA fragments. Circulating cell-free DNA released from apoptotic cells is uniformly truncated into 185- to 200-bp fragments [79, 80], whereas cell-free DNA released from necrotic tumor cells varies in length, which may lead to elevation of DNA with long fragments in plasma [30] or serum [81]. A study by Leon et al. [82] suggested that the cell-free DNA concentration was significantly increased in cancer patients compared with that in healthy individuals. Similar findings have also been demonstrated in several cancers such as periampullary cancer [80], breast cancer [81], colorectal cancer [80], esophageal cancer [83], head and neck cancer [84], renal cancer [85], melanoma [86], and prostate cancer [87].

\section{Clinical applications of ctDNA}

Tumor genotyping: detection of genetic and epigenetic alterations

In principle, ctDNA fragments contain genetic defects identical to those of tumor tissues, including point mutations, rearrangements, amplifications, MSI, LOH, and tumor-associated DNA methylation [88]. To perform blood-based tumor genotyping assays by using ctDNA will be greatly beneficial for guiding personalized cancer treatment (Table 2). 
Table 1 Technologies for circulating tumor DNA (ctDNA) detection

\begin{tabular}{|c|c|c|c|c|c|}
\hline Principle of detection & Method & Type of alteration & Advantage(s) & Limitation(s) & Selected reference(s) \\
\hline \multirow[t]{6}{*}{ PCR-based } & Nested real-time PCR & \multirow{6}{*}{$\begin{array}{l}\text { Known point mutations } \\
\text { such as KRAS, EGFR, } \\
\text { and PIK3CA hotspot } \\
\text { alterations }\end{array}$} & \multirow{6}{*}{ Ease of use, lowest cost } & \multirow{6}{*}{$\begin{array}{l}\text { Lower sensitivity, } \\
\text { only detect limited } \\
\text { genomic loci }\end{array}$} & {$[70]$} \\
\hline & ARMS/Scorpion PCR & & & & [116] \\
\hline & PCR-SSCP & & & & {$[117]$} \\
\hline & $\begin{array}{l}\text { Mutant allele-specific } \\
\text { PCR }\end{array}$ & & & & [118] \\
\hline & Mass spectrometry & & & & [119] \\
\hline & Bi-PAP-A amplification & & & & [120] \\
\hline \multirow[t]{3}{*}{ Digital PCR } & BEAMing & \multirow{3}{*}{$\begin{array}{l}\text { Known point muta- } \\
\text { tions, genomic rear- } \\
\text { rangements }\end{array}$} & \multirow[t]{3}{*}{ High sensitivity } & \multirow{3}{*}{$\begin{array}{l}\text { Only detect limited } \\
\text { genomic loci }\end{array}$} & [59] \\
\hline & $\begin{array}{l}\text { Droplet-based digital } \\
\text { PCR }\end{array}$ & & & & {$[56]$} \\
\hline & Microfluidic digital PCR & & & & [10] \\
\hline \multirow{5}{*}{$\begin{array}{l}\text { Targeted deep } \\
\text { sequencing }\end{array}$} & SafeSeq & \multirow{5}{*}{$\begin{array}{l}\text { Selected SNVs, CNVs, } \\
\text { and rearrangements } \\
\text { across targeted } \\
\text { regions }\end{array}$} & \multirow{5}{*}{$\begin{array}{l}\text { High sensitivity, rela- } \\
\text { tively inexpensive }\end{array}$} & \multirow{5}{*}{$\begin{array}{l}\text { Less comprehensive } \\
\text { than WES methods }\end{array}$} & {$[64]$} \\
\hline & TamSeq & & & & [57] \\
\hline & lon-AmpliSeq ${ }^{\mathrm{TM}}$ & & & & {$[66,68]$} \\
\hline & CAPP-Seq & & & & {$[68]$} \\
\hline & OnTarget & & & & [121] \\
\hline \multirow{2}{*}{$\begin{array}{l}\text { Whole-genome } \\
\text { sequencing }\end{array}$} & Digital karyotyping & \multirow{2}{*}{$\begin{array}{l}\text { Genome-wide SNVs, } \\
\text { CNVs, and rearrange- } \\
\text { ments }\end{array}$} & \multirow[t]{2}{*}{ Broad application } & \multirow[t]{2}{*}{ Expensive } & [73] \\
\hline & PARE & & & & {$[70,72,74]$} \\
\hline
\end{tabular}

$P C R$ polymerase chain reaction, $A R M S$ amplified refractory mutation system, $S S C P$ single-strand conformation polymorphism, $B$ - $P A P-A$ amplification bidirectional pyrophosphorolysis-activated polymerization allele-specific amplification, BEAMing beads, emulsion, amplification, and magnetics, SafeSeq safe sequencing system, TamSeq tagged amplicon deep sequencing, CAPP-Seq cancer personalized profiling by deep sequencing, PARE personalized analysis of rearranged ends, KRAS Kirsten rat sarcoma viral oncogene homolog, EGFR epidermal growth factor receptor, PIK3CA phosphatidylinositol-4,5-biphosphate 3-kinase, catalytic subunit alpha, SNV single-nucleotide variants, CNVs copy number variations, WES whole-exome sequencing

Table 2 Potential application of ctDNA in clinical oncology

\begin{tabular}{cccc}
\hline Cancer screening & Localized cancer & Metastatic cancer & Refractory cancer \\
\hline $\begin{array}{c}\text { Early diagnosis and } \\
\text { early intervention }\end{array}$ & $\begin{array}{c}\text { Identifying specific genomic } \\
\text { alterations to guide therapeutic } \\
\text { selection, monitoring tumor bur- } \\
\text { den and therapeutic responses, } \\
\text { detecting minimal residual dis- } \\
\text { ease, assessing risks of dissemina- } \\
\text { tion and recurrence }\end{array}$ & $\begin{array}{c}\text { Early identification of relapse and } \\
\text { treatment resistance, guidance of }\end{array}$ & $\begin{array}{c}\text { Understanding mechanism of resistance, determin- } \\
\text { therapeutic responses }\end{array}$ \\
& & \\
\hline
\end{tabular}

\section{Detection of tumor-specific mutations and CNVs}

Two separate studies in 1994 first described Kirsten rat sarcoma viral oncogene homolog (KRAS) and neuroblastoma RAS viral (v-ras) oncogene homolog (NRAS) mutations in the blood of pancreatic carcinoma [89] and leukemia patients [90]. During the past two decades, abundant mutations have been detected in the ctDNA of patients with various types of cancer [49]. Next generation sequencing has been directly applied to ctDNA analysis. Dawson et al. [10] used targeted or whole-genome sequencing to assess genetic mutations in tumors samples from 30 metastatic breast cancer patients, and designed personalized assays to quantify ctDNA genetic alterations. They found that ctDNA levels showed a greater dynamic range and associated with changes in tumor burden. Leary et al. [74] published the first whole-genome sequencing analysis of ctDNA. They successfully identified ctDNA in concentrations of less than $1 \%$ with a sensitivity $>90 \%$ and a specificity $>99 \%$. Single-nucleotide variants (SNVs) and CNV were detected in all advancedstage cancer patients, but not in healthy subjects [74]. Recently, Chan et al. [77] applied shotgun MPS of plasma DNA from cancer patients to scan the cancer genome and achieved the genome-wide profiling of CNVs and point mutations. Concordant genome-wide SNVs have been identified between tumor tissues and pre-surgical cellfree DNA. Most importantly, the structural alterations in plasma DNA entirely disappeared after surgery. Moreover, the CNV profile detected in ctDNA was derived from three primary tumor mixtures in a cancer patient, indicating that ctDNA sequencing is a valuable approach for studying tumor heterogeneity [77]. 


\section{Detection of MSI and LOH in ctDNA}

MSI, such as LOH, is frequently found in tumor tissues. Detection of MSI and LOH in ctDNA was first reported by Nawroz et al. [84] in 1996. To date, similar studies have been completed in breast, brain, colorectal, ovarian, and prostate cancers [49]. Recently, a study involving a large cohort of breast cancer patients $(n=388)$ showed that high LOH frequencies were associated with the aggressiveness of breast cancer, and in particular, the observed CCND2 loss was a strong indicator of an unfavorable prognosis [91].

\section{Detection of tumor-associated DNA methylation in ctDNA}

DNA methylation plays pivotal roles in gene regulation and genome stability. Genes with high levels of 5-methylcytosine in the promoter region are transcriptionally silent. This process is often dysregulated in tumor cells. Aberrations of DNA methylation in the gene promoter region or in the non-coding genomic sequences are associated with tumor initiation, dissemination and metastasis establishment, and progression [92]. The status of DNA methylation is very stable, even in the circulation; thus it can be assessed to monitor tumor-related processes. Aberrant DNA methylation has been first detected in the plasma and serum of lung [93], breast [94], and liver cancer patients in 1999 [95]. Since then, extensive studies have indicated the potential of ctDNA methylation as a diagnostic and prognostic marker for cancer patients [49, 96-98]. Recently, a study identified genome-wide ctDNA methylation in esophageal cancer patients, and observed highly concordant methylation profiles between ctDNA and corresponding tumor tissues [99]. Differential ctDNA methylation profiles were characterized to distinguish esophageal adenocarcinoma, precursors, and controls [99]. The study suggested that ctDNA can produce excellent methylation profiling on a genome-wide scale and serve as a useful tool to develop methylation-based biomarkers for clinical application.

\section{Monitoring tumor burden and therapeutic responses}

Dynamics of ctDNA has been investigated in various solid malignancies for the relationship between ctDNA levels, tumor burden, and therapeutic responses [10, $34,70,72,100,101]$. Protein biomarkers are conventionally used in cancer diagnosis and in the assessment of therapeutic responses, such as carcinoembryonic antigen (CEA), prostate-specific antigen (PSA), cancer antigen (CA) 19-9, and CA-125. Unfortunately, the specificity and reliability of these protein biomarkers are not satisfactory, and many malignancies even do not have any reliable protein biomarker [102, 103]. ctDNA carries comprehensive, inherently specific, and highly sensitive information, and thus possesses distinctive advantage over conventional protein biomarkers. Studies in melanoma [104, 105], breast [10], ovarian [57], and colon cancers [34, 106] have solidified the potential applications of ctDNA to monitor tumor burden dynamically and precisely during treatment process. ctDNA levels increased rapidly with disease progression and declined correspondingly after successful treatment [10, 34, 57, 104, 105]. Quantitative assessment of ctDNA levels could also be an important indicator of prognosis (Table 2). Some preliminary data supported an association between ctDNA levels and prognosis in cancer patients with advanced-stage disease [10, 107-109].

Treatment resistance is a major problem in the care of cancer patients. ctDNA can effectively assess the emergence of mutations associated with treatment resistance [110-114]. The molecular alterations of KRAS are causally associated with the onset of acquired resistance to anti-EGFR treatment of colorectal cancers. Detection of $K R A S$ variants in ctDNA of patients receiving anti-EGFR therapies can identify relapse 10 months before radiographic documentation of disease progression [111]. Furthermore, by using whole-exome sequencing, serial ctDNA analysis can provide an unbiased and comprehensive assessment of genomic alterations during the acquisition of treatment resistance [69].

ctDNA analysis can ultimately provide a global picture of genetic alterations, including the dynamic changes of the mutation profile as well as tumor heterogeneity and clonal evolution throughout the course of cancer treatment (Table 2). This global picture can help for designing combination treatments to minimize therapeutic resistance.

\section{Monitoring minimal residual disease}

ctDNA can be potentially applied to detect minimal residual disease after surgery or therapy with curative intent $[100,115]$. In certain type of cancers, respective surgery alone cures a large portion of patients with earlystage, localized tumor. However, no effective approach can discriminate which patients are cured and which have residual disease that will result in recurrence. Therefore, some patients potentially cured by surgery still receive adjuvant chemotherapy unnecessarily since lack of information. ctDNA is a potential marker for residual disease after resection to identify individuals at risk of relapse (Table 2). Studies show that assessment of tumorspecific mutations in plasma DNA following surgical resection can identify individuals with residual disease [89], and detect disease recurrence [84, 85]. The early prediction of recurrence will allow effective treatment strategies to be introduced at a time when disease burden is still minimal. 


\section{Challenges of ctDNA analysis on the path to clinical utility}

As a noninvasive "liquid biopsy," ctDNA is a promising biomarker that provides highly specific and complementary information in the diagnosis, prognosis, and management of cancer treatment. With the rapid advances and the decrease in the cost of next-generation sequencing, the technology brings a new alternative for unbiased ctDNA exploration. However, clinical routine practice is slow to adopt this approach since several challenges remain despite the remarkable progress in recent years. Most ctDNA studies focused on advanced-stage cancers with relatively high concentrations of ctDNA. Detailed experiences with early-stage cancer and low concentrations of ctDNA are lacking. High levels of normal DNA aggravated during inflammation and injury could dilute ctDNA and interfere ctDNA detection. Therefore, ctDNA analysis in some clinical settings may result from detection of nonprogressing benign lesions. In addition, the diverse technologies of ctDNA analysis need to be optimized and different platforms need to be standardized, and the appropriate analytic and clinical validity needs to be demonstrated, to control the pre-analytic phase and obtain robust and reproducible results. Most importantly, critical clinical standards need to be established, and welldesigned and sufficiently powered multicenter clinical trials involving large cohorts of patients and controls are required to validate ctDNA as clinical biomarker.

\section{Authors' contributions}

ZQ designed and wrote the manuscript; $V L$ and $C Z$ revised the manuscript; $Y T$ and $\mathrm{JL}$ co-designed, reviewed, and revised the manuscript. All authors read and approved the final manuscript.

\section{Author details \\ ${ }^{1}$ Department of Medicine, Cedars-Sinai Medical Center, David Geffen School of Medicine at UCLA, Los Angeles, California 90048, USA. ${ }^{2}$ School of Life Science and Technology, Xidian University, Xi'an 710126, Shaanxi, P. R. China. ${ }^{3}$ Keck School of Medicine, University of Southern California, Los Angeles, CA 90033, USA. ${ }^{4}$ Department of Pathology, Xinxiang Medical University, Xinxi- ang 453003, Henan, P. R. China.}

\section{Acknowledgements \\ This work was supported partly by the National Natural Science Foundation of China (No. 81227901), the Natural Science Basic Research Plan in Shaanxi Province of China (No. 2015JZ019), the Fundamental Research Funds for the Central Universities, National Cancer Institute of the National Institutes of Health (No. R00CA138914), and National Natural Science Foundation (No. 81372216).}

\section{Competing interests}

The authors declare that they have no competing interests.

Received: 2 November 2015 Accepted: 1 February 2016 Published online: 07 April 2016

\footnotetext{
References

1. Stewart BW, Wild C, International Agency for Research on Cancer, World Health Organization. World cancer report 2014. Lyon, Geneva: International Agency for Research on Cancer. WHO Press; 2014.
}

2. Valastyan S, Weinberg RA. Tumor metastasis: molecular insights and evolving paradigms. Cell. 2011;147(2):275-92. doi:10.1016/j. cell.2011.09.024

3. Meric-Bernstam F, Mills GB. Overcoming implementation challenges of personalized cancer therapy. Nat Rev Clin Oncol. 2012;9(9):542-8. doi:10.1038/nrclinonc.2012.127.

4. Vogelstein B, Papadopoulos N, Velculescu VE, Zhou S, Diaz LA Jr, Kinzler KW. Cancer genome landscapes. Science. 2013;339(6127):1546-58. doi:10.1126/science.1235122.

5. Marusyk A, Polyak K. Tumor heterogeneity: causes and consequences. Biochim Biophys Acta. 2010;1805(1):105-17. doi:10.1016/j. bbcan.2009.11.002.

6. Gerlinger M, Rowan AJ, Horswell S, Larkin J, Endesfelder D, Gronroos $\mathrm{E}$, et al. Intratumor heterogeneity and branched evolution revealed by multiregion sequencing. N Engl J Med. 2012;366(10):883-92. doi:10.1056/NEJMoa1113205.

7. Yates $L R$, Campbell PJ. Evolution of the cancer genome. Nat Rev Genet. 2012;13(11):795-806. doi:10.1038/nrg3317.

8. Aparicio $S$, Caldas $C$. The implications of clonal genome evolution for cancer medicine. N Engl J Med. 2013;368(9):842-51. doi:10.1056/ NEJMra1204892.

9. Heitzer E, Auer M, Gasch C, Pichler M, Ulz P, Hoffmann EM, et al. Complex tumor genomes inferred from single circulating tumor cells by array-CGH and next-generation sequencing. Cancer Res. 2013;73(10):2965-75. doi:10.1158/0008-5472.CAN-12-4140.

10. Dawson SJ, Tsui DW, Murtaza M, Biggs H, Rueda OM, Chin SF, et al. Analysis of circulating tumor DNA to monitor metastatic breast cancer. N Engl J Med. 2013;368(13):1199-209. doi:10.1056/NEJMoa1213261.

11. Mandel P, Metais P. Les acides nucleiques du plasma sanguin chez I' homme. Seances Soc Biol Fil. 1948;142:241-3 (in French).

12. Stroun M, Anker P, Maurice P, Lyautey J, Lederrey C, Beljanski M. Neoplastic characteristics of the DNA found in the plasma of cancer patients. Oncology. 1989:46(5):318-22.

13. Anker $P$, Mulcahy $H$, Chen $X Q$, Stroun M. Detection of circulating tumour DNA in the blood (plasma/serum) of cancer patients. Cancer Metastasis Rev. 1999;18(1):65-73.

14. Gormally E, Caboux E, Vineis P, Hainaut P. Circulating free DNA in plasma or serum as biomarker of carcinogenesis: practical aspects and biological significance. Mutat Res. 2007;635(2-3):105-17. doi:10.1016/j. mrrev.2006.11.002.

15. Fleischhacker M, Schmidt B. Circulating nucleic acids (CNAs) and cancer-a survey. Biochim Biophys Acta. 2007;1775(1):181-232. doi:10.1016/j.bbcan.2006.10.001

16. Schwarzenbach H, Stoehlmacher J, Pantel K, Goekkurt E. Detection and monitoring of cell-free DNA in blood of patients with colorectal cancer. Ann N Y Acad Sci. 2008;1 137:190-6. doi:10.1196/ annals.1448.025.

17. Schwarzenbach H, Alix-Panabieres C, Muller I, Letang N, Vendrell JP, Rebillard X, et al. Cell-free tumor DNA in blood plasma as a marker for circulating tumor cells in prostate cancer. Clin Cancer Res. 2009;15(3):1032-8. doi:10.1158/1078-0432.CCR-08-1910.

18. Schwarzenbach H, Muller V, Milde-Langosch K, Steinbach B, Pantel K. Evaluation of cell-free tumour DNA and RNA in patients with breast cancer and benign breast disease. Mol BioSyst. 2011;7(10):2848-54. doi:10.1039/c1 mb05197k.

19. Salvianti F, Pinzani P, Verderio P, Ciniselli CM, Massi D, De Giorgi V, et al. Multiparametric analysis of cell-free DNA in melanoma patients. PLoS One. 2012;7(11):e49843. doi:10.1371/journal.pone.0049843.

20. Park JL, Kim HJ, Choi BY, Lee HC, Jang HR, Song KS, et al. Quantitative analysis of cell-free DNA in the plasma of gastric cancer patients. Oncol Lett. 2012;3(4):921-6. doi:10.3892/ol.2012.592.

21. Delgado PO, Alves BC, Gehrke Fde S, Kuniyoshi RK, Wroclavski ML, Del Giglio A, et al. Characterization of cell-free circulating DNA in plasma in patients with prostate cancer. Tumour Biol. 2013;34(2):983-6. doi:10.1007/s13277-012-0634-6.

22. Friel AM, Corcoran C, Crown J, O'Driscoll L. Relevance of circulating tumor cells, extracellular nucleic acids, and exosomes in breast cancer. Breast Cancer Res Treat. 2010;123(3):613-25. doi:10.1007/ s10549-010-0980-2.

23. Ashworth TR. A case of cancer in which cells similar to those in the tumors were seen in the blood after death. Aus Med J. 1869:14:146-7. 
24. Pantel K, Brakenhoff $\mathrm{RH}$, Brandt B. Detection, clinical relevance and specific biological properties of disseminating tumour cells. Nat Rev Cancer. 2008:8(5):329-40. doi:10.1038/nrc2375.

25. Alix-Panabieres C, Pantel K. Circulating tumor cells: liquid biopsy of cancer. Clin Chem. 2013;59(1):110-8. doi:10.1373/ clinchem.2012.194258.

26. Pantel K, Alix-Panabieres C. Circulating tumour cells in cancer patients: challenges and perspectives. Trends Mol Med. 2010;16(9):398-406. doi:10.1016/j.molmed.2010.07.001.

27. Alix-Panabieres C, Pantel K. Technologies for detection of circulating tumor cells: facts and vision. Lab Chip. 2014;14(1):57-62. doi:10.1039/ c3lc50644d

28. Ilie M, Hofman V, Long E, Bordone O, Selva E, Washetine K, et al. Current challenges for detection of circulating tumor cells and cell-free circulating nucleic acids, and their characterization in non-small cell lung carcinoma patients. What is the best blood substrate for personalized medicine? Ann Transl Med. 2014;2(11):107. doi:10.3978/j. issn.2305-5839.2014.08.11

29. Stroun M, Lyautey J, Lederrey C, Olson-Sand A, Anker P. About the possible origin and mechanism of circulating DNA apoptosis and active DNA release. Clin Chim Acta. 2001;313(1-2):139-42.

30. Jahr S, Hentze H, Englisch S, Hardt D, Fackelmayer FO, Hesch RD, et al. DNA fragments in the blood plasma of cancer patients: quantitations and evidence for their origin from apoptotic and necrotic cells. Cancer Res. 2001;61(4):1659-65.

31. Chan KC, Zhang J, Hui AB, Wong N, Lau TK, Leung TN, et al. Size distributions of maternal and fetal DNA in maternal plasma. Clin Chem. 2004;50(1):88-92. doi:10.1373/clinchem.2003.024893.

32. Mouliere F, Robert B, Arnau Peyrotte E, Del Rio M, Ychou M, Molina F, et al. High fragmentation characterizes tumour-derived circulating DNA. PLoS One. 2011;6(9):e23418. doi:10.1371/journal.pone.0023418.

33. Diehl F, Li M, Dressman D, He Y, Shen D, Szabo S, et al. Detection and quantification of mutations in the plasma of patients with colorectal tumors. Proc Natl Acad Sci USA. 2005;102(45):16368-73. doi:10.1073/ pnas.0507904102.

34. Diehl F, Schmidt K, Choti MA, Romans K, Goodman S, Li M, et al. Circulating mutant DNA to assess tumor dynamics. Nat Med. 2008;14(9):98590. doi:10.1038/nm.1789.

35. Roninson IB, Broude EV, Chang BD. If not apoptosis, then what? Treatment-induced senescence and mitotic catastrophe in tumor cells. Drug Resist Updat. 2001;4(5):303-13. doi:10.1054/drup.2001.0213.

36. Wang BG, Huang HY, Chen YC, Bristow RE, Kassauei K, Cheng CC, et al. Increased plasma DNA integrity in cancer patients. Cancer Res. 2003;63(14):3966-8

37. Anker P, Stroun M, Maurice PA. Spontaneous release of DNA by human blood lymphocytes as shown in an in vitro system. Cancer Res. 1975;35(9):2375-82

38. Stroun M, Maurice P, Vasioukhin V, Lyautey J, Lederrey C, Lefort F, et al. The origin and mechanism of circulating DNA. Ann NY Acad Sci. 2000;906:161-8.

39. Stroun M, Lyautey J, Lederrey C, Mulcahy HE, Anker P. Alu repeat sequences are present in increased proportions compared to a unique gene in plasma/serum DNA: evidence for a preferential release from viable cells? Ann NY Acad Sci. 2001;945:258-64.

40. Rogers JC, Boldt D, Kornfeld S, Skinner A, Valeri CR. Excretion of deoxyribonucleic acid by lymphocytes stimulated with phytohemagglutinin or antigen. Proc Natl Acad Sci USA. 1972;69(7):1685-9.

41. Rogers JC. Identification of an intracellular precursor to DNA excreted by human lymphocytes. Proc Natl Acad Sci USA. 1976;73(9):3211-5.

42. Kohler C, Barekati Z, Radpour R, Zhong XY. Cell-free DNA in the circulation as a potential cancer biomarker. Anticancer Res. 2011;31(8):2623-8.

43. Chan KC, Jiang P, Chan CW, Sun K, Wong J, Hui EP, et al. Noninvasive detection of cancer-associated genome-wide hypomethylation and copy number aberrations by plasma DNA bisulfite sequencing. Proc Natl Acad Sci USA. 2013;110(47):18761-8. doi:10.1073/ pnas.1313995110.

44. Yu SC, Lee SW, Jiang P, Leung TY, Chan KC, Chiu RW, et al. High-resolution profiling of fetal DNA clearance from maternal plasma by massively parallel sequencing. Clin Chem. 2013;59(8):1228-37. doi:10.1373/ clinchem.2013.203679.
45. Lo YM, Zhang J, Leung TN, Lau TK, Chang AM, Hjelm NM. Rapid clearance of fetal DNA from maternal plasma. Am J Hum Genet. 1999;64(1):218-24. doi:10.1086/302205.

46. Lo YM, Leung SF, Chan LY, Chan AT, Lo KW, Johnson PJ, et al. Kinetics of plasma Epstein-Barr virus DNA during radiation therapy for nasopharyngeal carcinoma. Cancer Res. 2000;60(9):2351-5.

47. To EW, Chan KC, Leung SF, Chan LY, To KF, Chan AT, et al. Rapid clearance of plasma Epstein-Barr virus DNA after surgical treatment of nasopharyngeal carcinoma. Clin Cancer Res. 2003;9(9):3254-9.

48. Chan KC. Plasma Epstein-Barr virus DNA as a biomarker for nasopharyngeal carcinoma. Chin J Cancer. 2014;33(12):598-603. doi:10.5732/ cjc.014.10192.

49. Marzese DM, Hirose H, Hoon DS. Diagnostic and prognostic value of circulating tumor-related DNA in cancer patients. Expert Rev Mol Diagn. 2013;13(8):827-44. doi:10.1586/14737159.2013.845088.

50. Jung M, Klotzek S, Lewandowski M, Fleischhacker M, Jung K. Changes in concentration of DNA in serum and plasma during storage of blood samples. Clin Chem. 2003;49(6 Pt 1):1028-9.

51. Bjorkman L, Reich CF, Pisetsky DS. The use of fluorometric assays to assess the immune response to DNA in murine systemic lupus erythematosus. Scand J Immunol. 2003;57(6):525-33.

52. Tuaeva NO, Abramova ZI, Sofronov WV. The origin of elevated levels of circulating DNA in blood plasma of premature neonates. Ann NY Acad Sci. 2008;1137:27-30. doi:10.1196/annals.1448.043.

53. Chen Z, Feng J, Buzin CH, Liu Q, Weiss L, Kernstine K, et al. Analysis of cancer mutation signatures in blood by a novel ultra-sensitive assay: monitoring of therapy or recurrence in non-metastatic breast cancer. PLoS One. 2009:4(9):e7220. doi:10.1371/journal.pone.0007220.

54. Vogelstein B, Kinzler KW. Digital PCR. Proc Natl Acad Sci USA 1999;96(16):9236-41.

55. Hindson BJ, Ness KD, Masquelier DA, Belgrader P, Heredia NJ, Makarewicz AJ, et al. High-throughput droplet digital PCR system for absolute quantitation of DNA copy number. Anal Chem. 2011;83(22):8604-10. doi:10.1021/ac202028g.

56. Pekin D, Skhiri Y, Baret JC, Le Corre D, Mazutis L, Salem CB, et al. Quantitative and sensitive detection of rare mutations using droplet-based microfluidics. Lab Chip. 2011;11(13):2156-66. doi:10.1039/c1lc20128j.

57. Forshew T, Murtaza M, Parkinson C, Gale D, Tsui DW, Kaper F, et al. Noninvasive identification and monitoring of cancer mutations by targeted deep sequencing of plasma DNA. Sci Transl Med. 2012;4(136):136ra68. doi:10.1126/scitranslmed.3003726.

58. Wang J, Ramakrishnan R, Tang Z, Fan W, Kluge A, Dowlati A, et al. Quantifying EGFR alterations in the lung cancer genome with nanofluidic digital PCR arrays. Clin Chem. 2010;56(4):623-32. doi:10.1373/ clinchem.2009.134973.

59. Dressman D, Yan H, Traverso G, Kinzler KW, Vogelstein B. Transforming single DNA molecules into fluorescent magnetic particles for detection and enumeration of genetic variations. Proc Natl Acad Sci USA. 2003;100(15):8817-22. doi:10.1073/pnas.1133470100.

60. Higgins MJ, Jelovac D, Barnathan E, Blair B, Slater S, Powers P, et al. Detection of tumor PIK3CA status in metastatic breast cancer using peripheral blood. Clin Cancer Res. 2012;18(12):3462-9. doi:10.1158/1078-0432.CCR-11-2696.

61. Ignatiadis M, Dawson SJ. Circulating tumor cells and circulating tumor DNA for precision medicine: dream or reality? Ann Oncol. 2014;25(12):2304-13. doi:10.1093/annonc/mdu480.

62. Haber DA, Velculescu VE. Blood-based analyses of cancer: circulating tumor cells and circulating tumor DNA. Cancer Discov. 2014;4(6):65061. doi:10.1158/2159-8290.CD-13-1014.

63. Lanman RB, Mortimer SA, Zill OA, Sebisanovic D, Lopez R, Blau S, et al. Analytical and clinical validation of a digital sequencing panel for quantitative, highly accurate evaluation of cell-free circulating tumor DNA. PLoS One. 2015;10(10):e0140712. doi:10.1371/journal.pone.0140712.

64. Kinde I, Wu J, Papadopoulos N, Kinzler KW, Vogelstein B. Detection and quantification of rare mutations with massively parallel sequencing. Proc Natl Acad Sci USA. 2011;108(23):9530-5. doi:10.1073/ pnas.1105422108.

65. Bettegowda C, Sausen M, Leary RJ, Kinde I, Wang Y, Agrawal N, et al. Detection of circulating tumor DNA in early- and late-stage human malignancies. Sci Transl Med. 2014;6(224):224ra24. doi:10.1126/ scitranslmed.3007094. 
66. Rothe F, Laes JF, Lambrechts D, Smeets D, Vincent D, Maetens M, et al. Plasma circulating tumor DNA as an alternative to metastatic biopsies for mutational analysis in breast cancer. Ann Oncol. 2014;25(10):195965. doi:10.1093/annonc/mdu288.

67. Carreira S, Romanel A, Goodall J, Grist E, Ferraldeschi R, Miranda S, et al. Tumor clone dynamics in lethal prostate cancer. Sci Transl Med. 2014;6(254):254ra125. doi:10.1126/scitranslmed.3009448.

68. Newman AM, Bratman SV, To J, Wynne JF, Eclov NC, Modlin LA, et al. An ultrasensitive method for quantitating circulating tumor DNA with broad patient coverage. Nat Med. 2014;20(5):548-54. doi:10.1038/ nm.3519.

69. Murtaza M, Dawson SJ, Tsui DW, Gale D, Forshew T, Piskorz AM, et al. Non-invasive analysis of acquired resistance to cancer therapy by sequencing of plasma DNA. Nature. 2013;497(7447):108-12. doi:10.1038/nature12065.

70. McBride DJ, Orpana AK, Sotiriou C, Joensuu H, Stephens PJ, Mudie $L$, et al. Use of cancer-specific genomic rearrangements to quantify disease burden in plasma from patients with solid tumors. Genes Chromosomes Cancer. 2010;49(11):1062-9. doi:10.1002/gcc.20815.

71. Shaw JA, Page K, Blighe K, Hava N, Guttery D, Ward B, et al. Genomic analysis of circulating cell-free DNA infers breast cancer dormancy. Genome Res. 2012;22(2):220-31. doi:10.1101/gr.123497.111.

72. Leary RJ, Kinde I, Diehl F, Schmidt K, Clouser C, Duncan C, et al. Development of personalized tumor biomarkers using massively parallel sequencing. Sci Transl Med. 2010;2(20):20ra14. doi:10.1126/ scitranslmed.3000702.

73. Wang TL, Maierhofer C, Speicher MR, Lengauer C, Vogelstein B, Kinzler KW, et al. Digital karyotyping. Proc Natl Acad Sci USA. 2002:99(25):16156-61. doi:10.1073/pnas.202610899.

74. Leary RJ, Sausen M, Kinde I, Papadopoulos N, Carpten JD, Craig D, et al. Detection of chromosomal alterations in the circulation of cancer patients with whole-genome sequencing. Sci Transl Med. 2012:4(162):162ra54. doi:10.1126/scitranslmed.3004742.

75. Wang TL, Diaz LA Jr, Romans K, Bardelli A, Saha S, Galizia G, et al. Digital karyotyping identifies thymidylate synthase amplification as a mechanism of resistance to 5-fluorouracil in metastatic colorectal cancer patients. Proc Natl Acad Sci USA. 2004;101(9):3089-94. doi:10.1073/ pnas.0308716101.

76. Duncan CG, Leary RJ, Lin JC, Cummins J, Di C, Schaefer CF, et al. Identification of microbial DNA in human cancer. BMC Med Genomics. 2009;2:22. doi:10.1186/1755-8794-2-22.

77. Chan KC, Jiang P, Zheng YW, Liao GJ, Sun H, Wong J, et al. Cancer genome scanning in plasma: detection of tumor-associated copy number aberrations, single-nucleotide variants, and tumoral heterogeneity by massively parallel sequencing. Clin Chem. 2013;59(1):211-24. doi:10.1373/clinchem.2012.196014

78. Heitzer E, Ulz P, Belic J, Gutschi S, Quehenberger F, Fischereder K, et al. Tumor-associated copy number changes in the circulation of patients with prostate cancer identified through whole-genome sequencing. Genome Med. 2013;5(4):30. doi:10.1186/gm434.

79. Giacona MB, Ruben GC, Iczkowski KA, Roos TB, Porter DM, Sorenson GD. Cell-free DNA in human blood plasma: length measurements in patients with pancreatic cancer and healthy controls. Pancreas. 1998;17(1):89-97.

80. Umetani N, Kim J, Hiramatsu S, Reber HA, Hines OJ, Bilchik AJ, et al. Increased integrity of free circulating DNA in sera of patients with colorectal or periampullary cancer: direct quantitative PCR for ALU repeats. Clin Chem. 2006;52(6):1062-9. doi:10.1373/clinchem.2006.068577.

81. Umetani N, Giuliano AE, Hiramatsu SH, Amersi F, Nakagawa T, Martino $\mathrm{S}$, et al. Prediction of breast tumor progression by integrity of free circulating DNA in serum. J Clin Oncol. 2006;24(26):4270-6. doi:10.1200/ JCO.2006.05.9493.

82. Leon SA, Shapiro B, Sklaroff DM, Yaros MJ. Free DNA in the serum of cancer patients and the effect of therapy. Cancer Res. 1977:37(3):646-50.

83. Tomita H, Ichikawa D, Ikoma D, Sai S, Tani N, Ikoma H, et al. Quantification of circulating plasma DNA fragments as tumor markers in patients with esophageal cancer. Anticancer Res. 2007;27(4C):2737-41.

84. Nawroz H, Koch W, Anker P, Stroun M, Sidransky D. Microsatellite alterations in serum DNA of head and neck cancer patients. Nat Med. 1996;2(9):1035-7.
85. Gang F, Guorong L, An Z, Anne GP, Christian G, Jacques T. Prediction of clear cell renal cell carcinoma by integrity of cell-free DNA in serum. Urology. 2010;75(2):262-5. doi:10.1016/j.urology.2009.06.048.

86. Pinzani P, Salvianti F, Zaccara S, Massi D, De Giorgi V, Pazzagli M, et al. Circulating cell-free DNA in plasma of melanoma patients: qualitative and quantitative considerations. Clin Chim Acta. 2011;412(23-24):2141-5. doi:10.1016/j.cca.2011.07.027.

87. Hanley R, Rieger-Christ KM, Canes D, Emara NR, Shuber AP, Boynton $K A$, et al. DNA integrity assay: a plasma-based screening tool for the detection of prostate cancer. Clin Cancer Res. 2006;12(15):4569-74. doi:10.1158/1078-0432.CCR-06-0130.

88. Elshimali Yl, Khaddour H, Sarkissyan M, Wu Y, Vadgama JV. The clinical utilization of circulating cell free DNA (CCFDNA) in blood of cancer patients. Int J Mol Sci. 2013;14(9):18925-58. doi:10.3390/ ijms140918925.

89. Sorenson GD, Pribish DM, Valone FH, Memoli VA, Bzik DJ, Yao SL. Soluble normal and mutated DNA sequences from singlecopy genes in human blood. Cancer Epidemiol Biomarkers Prev. 1994;3(1):67-71.

90. Vasioukhin V, Anker P, Maurice P, Lyautey J, Lederrey C, Stroun M. Point mutations of the $\mathrm{N}$-ras gene in the blood plasma DNA of patients with myelodysplastic syndrome or acute myelogenous leukaemia. $\mathrm{Br}$ J Haematol. 1994;86(4):774-9.

91. Schwarzenbach H, Eichelser C, Kropidlowski J, Janni W, Rack B, Pantel K. Loss of heterozygosity at tumor suppressor genes detectable on fractionated circulating cell-free tumor DNA as indicator of breast cancer progression. Clin Cancer Res. 2012;18(20):5719-30. doi:10.1158/10780432.CCR-12-0142.

92. Heyn H, Esteller M. DNA methylation profiling in the clinic: applications and challenges. Nat Rev Genet. 2012;13(10):679-92. doi:10.1038/ nrg3270.

93. Esteller M, Sanchez-Cespedes M, Rosell R, Sidransky D, Baylin SB, Herman JG. Detection of aberrant promoter hypermethylation of tumor suppressor genes in serum DNA from non-small cell lung cancer patients. Cancer Res. 1999;59(1):67-70.

94. Silva JM, Dominguez G, Villanueva MJ, Gonzalez R, Garcia JM, Corbacho $C$, et al. Aberrant DNA methylation of the p16INK4a gene in plasma DNA of breast cancer patients. Br J Cancer. 1999;80(8):1262-4. doi:10.1038/sj.bjc.6690495.

95. Wong $\mathrm{H}$, Lo YM, Zhang J, Liew CT, Ng MH, Wong N, et al. Detection of aberrant p16 methylation in the plasma and serum of liver cancer patients. Cancer Res. 1999;59(1):71-3.

96. Kawakami K, Brabender J, Lord RV, Groshen S, Greenwald BD, Krasna MJ, et al. Hypermethylated APC DNA in plasma and prognosis of patients with esophageal adenocarcinoma. J Natl Cancer Inst. 2000;92(22):1805-11.

97. Lecomte T, Berger A, Zinzindohoue F, Micard S, Landi B, Blons H, et al. Detection of free-circulating tumor-associated DNA in plasma of colorectal cancer patients and its association with prognosis. Int J Cancer. 2002;100(5):542-8. doi:10.1002/ijc.10526.

98. Warton K, Samimi G. Methylation of cell-free circulating DNA in the diagnosis of cancer. Front Mol Biosci. 2015;2:13. doi:10.3389/ fmolb.2015.00013.

99. Zhai R, Zhao Y, Su L, Cassidy L, Liu G, Christiani DC. Genome-wide DNA methylation profiling of cell-free serum DNA in esophageal adenocarcinoma and Barrett esophagus. Neoplasia. 2012;14(1):29-33.

100. Diaz LA Jr, Bardelli A. Liquid biopsies: genotyping circulating tumor DNA. J Clin Oncol. 2014;32(6):579-86. doi:10.1200/JCO.2012.45.2011.

101. Lipson EJ, Velculescu VE, Pritchard TS, Sausen M, Pardoll DM, Topalian SL, et al. Circulating tumor DNA analysis as a real-time method for monitoring tumor burden in melanoma patients undergoing treatment with immune checkpoint blockade. J Immunother Cancer. 2014;2(1):42 doi:10.1186/s40425-014-0042-0.

102. Yoshimasu T, Maebeya S, Suzuma T, Bessho T, Tanino H, Arimoto J, et al. Disappearance curves for tumor markers after resection of intrathoracic malignancies. Int J Biol Markers. 1999;14(2):99-105.

103. Ito K, Hibi K, Ando H, Hidemura K, Yamazaki T, Akiyama S, et al. Usefulness of analytical CEA doubling time and half-life time for overlooked synchronous metastases in colorectal carcinoma. Jpn J Clin Oncol. 2002;32(2):54-8. 
104. Shinozaki M, O’Day SJ, Kitago M, Amersi F, Kuo C, Kim J, et al. Utility of circulating B-RAF DNA mutation in serum for monitoring melanoma patients receiving biochemotherapy. Clin Cancer Res. 2007;13(7):206874. doi:10.1158/1078-0432.CCR-06-2120.

105. Bidard FC, Madic J, Mariani P, Piperno-Neumann S, Rampanou A, Servois $\checkmark$, et al. Detection rate and prognostic value of circulating tumor cells and circulating tumor DNA in metastatic uveal melanoma. Int J Cancer. 2014;134(5):1207-13. doi:10.1002/ijc.28436.

106. Tie J, Kinde I, Wang Y, Wong HL, Roebert J, Christie M, et al. Circulating tumor DNA as an early marker of therapeutic response in patients with metastatic colorectal cancer. Ann Oncol. 2015;26(8):1715-22. doi:10.1093/annonc/mdv177.

107. Pathak AK, Bhutani M, Kumar S, Mohan A, Guleria R. Circulating cell-free DNA in plasma/serum of lung cancer patients as a potential screening and prognostic tool. Clin Chem. 2006;52(10):1833-42. doi:10.1373/ clinchem.2005.062893.

108. Nygaard AD, Garm Spindler KL, Pallisgaard N, Andersen RF, Jakobsen A The prognostic value of KRAS mutated plasma DNA in advanced nonsmall cell lung cancer. Lung Cancer. 2013;79(3):312-7. doi:10.1016/j. lungcan.2012.11.016.

109. Olsson E, Winter C, George A, Chen Y, Howlin J, Tang MH, et al. Serial monitoring of circulating tumor DNA in patients with primary breast cancer for detection of occult metastatic disease. EMBO Mol Med. 2015;7(8):1034-47. doi:10.15252/emmm.201404913.

110. Diaz LA Jr, Williams RT, Wu J, Kinde I, Hecht JR, Berlin J, et al. The molecular evolution of acquired resistance to targeted EGFR blockade in colorectal cancers. Nature. 2012;486(7404):537-40. doi:10.1038/ nature11219.

111. Misale S, Yaeger R, Hobor S, Scala E, Janakiraman M, Liska D, et al. Emergence of KRAS mutations and acquired resistance to anti-EGFR therapy in colorectal cancer. Nature. 2012;486(7404):532-6. doi:10.1038/ nature11156.

112. Misale S, Arena S, Lamba S, Siravegna G, Lallo A, Hobor S, et al. Blockade of EGFR and MEK intercepts heterogeneous mechanisms of acquired resistance to anti-EGFR therapies in colorectal cancer. Sci Transl Med. 2014;6(224):224ra26. doi:10.1126/scitranslmed.3007947.
113. Bardelli A, Corso S, Bertotti A, Hobor S, Valtorta E, Siravegna G, et al. Amplification of the MET receptor drives resistance to anti-EGFR therapies in colorectal cancer. Cancer Discov. 2013;3(6):658-73. doi:10.1158/2159-8290.CD-12-0558.

114. De Mattos-Arruda L, Cortes J, Santarpia L, Vivancos A, Tabernero J, Reis-Filho JS, et al. Circulating tumour cells and cell-free DNA as tools for managing breast cancer. Nat Rev Clin Oncol. 2013;10(7):377-89. doi:10.1038/nrclinonc.2013.80

115. Siravegna G, Bardelli A. Genotyping cell-free tumor DNA in the blood to detect residual disease and drug resistance. Genome Biol. 2014;15(8):449. doi:10.1186/s13059-014-0449-4.

116. Board RE, Wardley AM, Dixon JM, Armstrong AC, Howell S, Renshaw $\mathrm{L}$, et al. Detection of PIK3CA mutations in circulating free DNA in patients with breast cancer. Breast Cancer Res Treat. 2010;120(2):461-7. doi:10.1007/s10549-010-0747-9.

117. Wang JY, Hsieh JS, Chang MY, Huang TJ, Chen FM, Cheng TL, et al. Molecular detection of APC, K- ras, and p53 mutations in the serum of colorectal cancer patients as circulating biomarkers. World J Surg. 2004;28(7):721-6. doi:10.1007/s00268-004-7366-8.

118. Yamada T, Nakamori S, Ohzato H, Oshima S, Aoki T, Higaki N, et al. Detection of K-ras gene mutations in plasma DNA of patients with pancreatic adenocarcinoma: correlation with clinicopathological features. Clin Cancer Res. 1998;4(6):1527-32.

119. Perkins G, Yap TA, Pope L, Cassidy AM, Dukes JP, Riisnaes R, et al. Multipurpose utility of circulating plasma DNA testing in patients with advanced cancers. PLoS One. 2012;7(11):e47020. doi:10.1371/journal. pone.0047020.

120. Shi J, Liu Q, Sommer SS. Detection of ultrarare somatic mutation in the human TP53 gene by bidirectional pyrophosphorolysisactivated polymerization allele-specific amplification. Hum Mutat. 2007;28(2):131-6. doi:10.1002/humu.20423.

121. Thompson JD, Shibahara G, Rajan S, Pel J, Marziali A. Winnowing DNA for rare sequences: highly specific sequence and methylation based enrichment. PLoS One. 2012;7(2):e31597. doi:10.1371/journal. pone.0031597.

\section{Submit your next manuscript to BioMed Central and we will help you at every step:}

- We accept pre-submission inquiries

- Our selector tool helps you to find the most relevant journal

- We provide round the clock customer support

- Convenient online submission

- Thorough peer review

- Inclusion in PubMed and all major indexing services

- Maximum visibility for your research

Submit your manuscript at www.biomedcentral.com/submit 